\title{
XXVI. Inquiry how far the theory of M. Elie de Beaumont concerning the parallelism of lines of elevation of the same geological æra, is agreeable to the phænomena as exhibited in Great Britain
}

Rev. W.D. Conybeare M.A. F.R.S. V.P.G.S.

To cite this article: Rev. W.D. Conybeare M.A. F.R.S. V.P.G.S. (1832) XXVI. Inquiry how far the theory of M. Elie de Beaumont concerning the parallelism of lines of elevation of the same geological æra, is agreeable to the phænomena as exhibited in Great Britain , Philosophical Magazine Series 3, 1:2, 118-126, DOI: 10.1080/14786443208647848

To link to this article: http://dx.doi.org/10.1080/14786443208647848

曲 Published online: 01 Jun 2009.

Submit your article to this journal ¿

Џll Article views: 2

Q View related articles ¿ 


\section{Rev. W. D. Conybeare on M. de Beaumont's Theory}

heavy timber can be procured nearly at the price of Memel, there will be no advantage derived from using it, so far as strength is a matter of consideration. But for its hardness, it may be preferable for blocks and for cabinet work.

Mr. Barlow supposes I have been misled by the small error in his formula, at the head of the sixth column. Being well aware of the principle upon which that column was formed, I made use of the correct formula ; and although it may appear strange, it is quite true that I did not discover the error until pointed ont by Mr. Barlow in his last paper.

The above remarks are not intended to depreciate the value of Tonquin Bean and the other species of wood in the market, but simply to prove that a species of wood (Memel Deal) which is now supplied in large quantities, will answer all the purposes of the builder. I sincerely hope that whenever opportunity occurs, either to Mr. Barlow or others, they will continue to favour the public with similar valuable information through the medium of your Magazine.

I remain, Gentlemen, yours very truly,

Leighton, July 11, 1832.

B. Bevan.

XXVI. Inquiry how far the Theory of M. Elie de Beaumont concerning the Parallelism of Lines of Elevation of the same Geological Zra, is agreeable to the Phanomena as exhibited in Great Britain. By the Rev. W. D. Conybeare, M.A. F.R.S. V.P.G.S. Instit. Reg. Soc. Paris.*

THE following remarks were drawn up by the author, in consequence of an inquiry proposed to him by the British Association for the Promotion of Science, at its first meeting atYork, in 1831, " how far the theory of M. Elie de Beaumont, concerning the parallelism of the lines of elevation produced by geological convulsions of the same æra, appeared to be confirmed by the phænomena of our own island." This question was referred to Professor Sedgwick and Mr. Conybeare; but circumstances having prevented their communication, the latter alone is responsible for the views contained in the present memoir; although, in the hope that some opportunity of intercourse would have occurred, he may occasionally have used the plural number. He has now only to add his earnest hope that nothing in the following communication will be so misconstrued, as to seem to imply any other feelings than those of the highest respect for the very distinguished talents of $M$. de Beaumont; for with them, on the contrary, from the period

* Communicated by the Author. 
of the short geological excursion he had the pleasure to make in his company during his visit to England, he has ever been most deeply impressed; and on the present subject he regards the views M. de Beaumont has announced, as exhibiting the first attempt to take a generalized and combined survey of some of the most important phænomena which fall within the province of our science, and as one of the most masterly contributions which that science has recently received. But there will always be some danger, when new generalizations first burst on the mind, of their being carried too far; and this danger will be in proportion to the ardour and vigour of the intellect from which they emanate. A fair and candid consideration of conflicting phænomena appears to be the only way of guarding against this danger: the character which Aristotle has given of Plato, " he doubted and investigated," must be that of the sincere lover of philosophical truth in every age.

The sectional researches proposed by the British Association being simply intended to invite discussion, the publication of any materials collected for the purpose remains, of course, with the contributors. The accompanying paper is therefore offered to the Editors of the Philosophical Magazine and Journal of Science, should it suit their pages.

Sully, July 4, 1832.

The question referred to our consideration by the former Meeting of this Society may be thus briefly stated. If we examine the phænomena which appear to have resulted from the action of the causes which have elerated at various geological periods the strata of the earth's crust, especially with reference to the line of direction in which those causes have acted, how far does it appear that these phænomena,-as presented by our own island, - confirm or militate against the hypothesis announced by $M$. Elie de Beaumont, - as resulting from his observations on the principal continental chains,- that the elevating forces which have acted during the same geological periods have acted in parallel lines of direction; and, $\boldsymbol{e}$ contra, that those whose activity must be referred to different epochs have not acted in parallel lines.*

In attempting an answer to this question, it may be observed, that as the conclusions of geological science ordinarily must be deduced from the generalization of very multifarious local details widely scattered, and such as can be collected only by the united and long continued exertions of many independent observers; so it were worse than presumptuous for individuals entering for the first time on a branch of the subject hitherto

* An Extract from M. de Beaumont's exposition of his hypothesis will be found in Phil. Mag, and Annals, N.S. vol. x. p. 241.-EDit. 


\section{Rev. W. D. Conybeare on M. de Beaumont's Theory}

almost unexplored, to pretend to offer more than a partial and imperfect contribution to its investigation, requiring much extension, and probably many corrections, before it can be considered as having accomplished anything beyond a general tracing out of the line of inquiry to be pursued.

The first point in this inquiry is obviously to determine the geological epochs to which the several elevations we observe should be referred. Now we have direct evidence which can enable us to do this, in very few cases; those, namely, in which, as in the Isle of Wight, we observe the immediate contact of the strata affected by the elevating force, with those which have been unaffected by it; and where moreover these strata also are terms immediately following one another in the regular geological series:-it is evident that this second condition is no less essential to determine the exact geological æra of the disturbance than the first; otherwise, where disturbed and undisturbed strata of remote age are in contact, the disturbing force may have acted during any portion of the long interval which must have elapsed between the deposition of the earlier and later formations : $e . g$. in the Boulogne district at Hardinghen we see the elevated strata of carboniferous strata and coal at the foot of the horizontal strata of chalk; and near Namur, in contact even with the tertiary formations. Now it is evident, that so far as the indications afforded by these localities are concerned, the disturbing forces may have acted at any time between the formation of the carboniferous rocks and the tertiary deposits; and it is only by extending our observations across the transition chains of the Ardennes, - which appear to have been affected by the same disturbances, and which abut on the South against undisturbed horizontal strata of new red sandstone, muschelkalk and keuper,-that we can assign the epoch at the close of the carboniferous period, and anterior to the formation of the new red sandstone, as the probable geological date of the agency of the disturbing force.

In many cases, however, we are not thus able to trace the disturbed district on any of its boundaries in contact with undisturbed beds immediately consecutive in age to some of the disturbed strata; but are reduced to reason from the looser analogy afforded by similar disturbances of the same rocks, but in unconnected geological localities; and it need not be urged that we should be careful not to assign too much importance to conclusions thus obtained.

Again; even as to the convulsions affecting the very same geographical district, it is too much to assume, without distinct evidence, that they have all been produced by one single shock, rather than by a series which may have occurred at 
intervals through a long period of ages : thus in the example cited, of the transition rocks of the Ardennes and the coalfields of the Meuse, it is evident that all the rocks anterior to the new red have been violently convulsed, and those subsequent have been little, if at all thus affected. But who shall say that all this disturbance was produced at one blow? This point, indeed, admits of determination by carefully examining whether a general conformity does or does not pervade the whole of the disturbed series;-for if there be anything like general interruptions in that conformity, every such interruption would clearly indicate a distinct æra of convulsion. Now, à priori, it should certainly appear that the idea of a series of successive convulsions seems most conformable to the only analogy presented by actual causes, the operations of volcanic forces; and the careful and minute examinations which would be necessary to ascertain every interruption of conformity in the strata of the disturbed districts have hitherto scarcely in any single instance been accurately made.

Having thus candidly avowed the difficulties and obscurities which hitherto overcloud this important branch of geological inquiry, we may proceed to state the few data on the subject which are as yet to be considered as tolerably ascertained, so far as the geology of this Island is concerned; and in doing this we shall find it most convenient to begin with the convulsions of the most recent order which have been here observed; those, namely, which have occurred during the period of the tertiary formations. The tertiary formations, and the chalk on which they rest, have participated in the general elevation of all the secondary strata of the Island, of which the general line of bearing is from N.E. to S.W., but there is no appearance whatever of this elevation having been the result of any violent sudden or single convulsion; on the contrary, everything indicates that it was a gradual, gentle, and protracted upheaving (to borrow a German term), continued without interruption during the whole period of the formation of all these strata; or perhaps some persons may be inclined to refer it rather to an equally progressive depression of the basins of the surrounding ocean : as all the phrnomena simply indicate a relative change of level, they will admit an equally ready explanation on either hypothesis. We may observe a very general tendency to parallelism between this line, (although the result of a cause certainly continuing to act in the same direction in the tertiary epoch, and the earlier and more violent convulsions which we shall hereafter find to have affected the older carboniferous strata before the deposition Third Series. Vol. 1. No. 2. Avg. 1832. 


\section{Rev. W. D. Conybeare on M. de Beaumont's Theory}

of the new red sandstone; for the general line (N.E. S.W.) above indicated, may be more correctly described as a curve running nearly $\mathbf{N}$. and $\mathbf{S}$. in the northern part of its course, and trending towards an $\mathrm{E}$. and $\mathrm{W}$. direction towards the South; and in like manner we find the carboniferous lines of elevation generally ranging $N$. and $S$. in our northern counties, and $\mathrm{E}$. and $\mathrm{W}$. in the southern. But independently of this general elevation, we find in the southern counties three parallel lines of elevation ranging $\mathrm{E}$. and $\mathrm{W}$, and indicative of more abrupt and violent action, which appears to have occurred during the tertiary epoch, and which may very probably be regarded as strictly contemporaneous. The first and most important of these lines of disturbance, is that which having traversed the Isle of Wight, strikes and ranges through the peninsula of Purbeck, and then produces the anticlinal line and parallel faults of the Weymouth district; thus extending over more than sixty miles. It must have produced an angular movement of the strata of many thousand feet, as it has thrown the chalk, plastic clay, and London clay into a vertical position. The section in Alum Bay distinctly exhibiting the contact of the disturbed and undisturbed strata, shows this derangement to have been effected by a single and most violent convulsion, of which the æra is most distinctly marked and precisely limited, being subsequent to the formation of London clay, and anterior to the alternations of fluviatile and marine deposits which characterize the basins of the Isle of Wight and Paris.

II. The anticlinal line of the Weald of Kent and Sussex, ranging from the North of Hastings to the North of Petersfield. - This is the cause of the elevation of the north and south chalky downs, and its disturbing effects may be most strongly traced in the narrow chalky ridge of the Hogsback (in the former), where the strata are considerably inclined: it may very probably be referred to the same æra as the foregoing line of disturbance, to which it is very nearly parallel. We may consider this anticlinal line as prolonged through the chalk by Winchester, and a little north of Salisbury, and thus reaching the Vale of Wardour, which is what Professor Buckland terms a Valley of Elevation: here the Portland limestone is thrown up, and the strata often considerably inclined. On the whole, however, the line now described is rather an anticlinal line of very gentle curvature, than one indicating violent disturbance. It is impossible to dismiss this line without observing how exactly parallel it is to the much older lines of elevation of the transition strata of the Quantock Hills and the Forest of 
Exmoor, which, when the eye glances over the map, appear to be its prolongation, and yet are really anterior to the age of the new red sandstone*.

III. A third parallel anticlinal line traverses the Vale of Pewsey, another valley of elevation on the greensand, separating the chalky ranges of Salisbury Plain and Marlborough Downs.- The protrusion of the greensand, in the prolongation of this line at Ham and Kingsclere, (see Buckland's paper ${ }^{\text {, }}$, Geol. Trans. 2nd series, vol. ii.) within the western angle of the London basin, may be referred to the same line of elevation, which will give it an extent of about 30 miles. I am not aware that its effect on the contiguous tertiary strata has been noticed, and can therefore only conjecture that it will probably, on examination, prove exactly contemporaneous with that of the Isle of Wight.

The above elevations, that of the Isle of Wight certainly, and those of the Weald and Vale of Pewsey, by the most probable analogy appear to have taken place subsequently to the formation of the inferior tertiary strata, and before the more recent beds. Elie de Beaumont assigns only the systems of Corsica and Sardinia to this epoch, and characterizes them as having a north and south direction; whereas our examples uniformly range $\mathrm{E}$. and $\mathrm{W}$.

Supplement to 1.-Although in the northern portion of our Island the absence of cretaceous and tertiary formations deprive us of this direct test of the æra of the disturbances which have there affected the strata, yet the association of many of these disturbances with apparently the newest varieties of the trap formation, and their intimate analogies, in general direction and in most of their geological circumstances, with those which we trace on the opposite side of a narrow channel, in. the basaltic area of Ireland, must at once induce us to refer them to a similar age; and in Ireland this is shown, by the presence of the chalk through which the basaltic eruptions have burst and overflowed, to be posterior to that of the cretaceous formation. On the Scotch coast, in Skye and Mull, we only see the basalt in contact with the oolites and lias, which, as at Portrush, \&c. in Ireland, are dislocated, altered, and overflowed by it. But to consider the case more generally, we shall find the general bearing of all the strata in Scotland, as in England, N.E. and S.W., and the same line is protracted into Ireland : this is the general bearing of the southern

* See Geol. Trans. vol. ii. 2nd series, for Dr. Fitton's Hastings Section, and those of the Western Weald, where the anticlinal line ranges through Hastings, and comes north of Petersfield.

+ An abstract of this paper will be found in Phil. Mag. vol. lxv. p.214.-ED. R 2 


\section{Rev. W. D. Conybeare on M. de Beaumont's Theory}

transition chain of Scotland, called the Lead Hills, which is continued on the Irish coast by the transition ranges of Down; of the primitive chain of the Grampians, continued in Ireland by the lines of the Derry mountains, \&c.; and of the principal undulations of the Grampians, as evidenced by the direction of the great depression which affords a line for the Caledonian canal.

Much of this process of elevation appears to have been like the general elevation of the English strata, gradual and gentle; at the same time that it ranges exactly parallel to many lines of disturbance which have been evidently violent, and produced by sudden convulsions limited to definite single periods. This general elevation clearly continued to act through the tertiary period, because in the Irish portion we see the terminal escarpments of the chalk and of the incumbent ridges of basalt conforming to these general lines. The disturbances effected in the oolitic strata of Scotland, near their contact with the granitic chains of Sutherland, are obviously of indefinite age. We shall notice them, therefore, more at length when speaking of the disturbances generally affecting the oolites, and only mention them here to state that we have no clear evidence which negatives the supposition that they may have taken place even as late as the tertiary period.

Supplement to II. Disturbances during the period between the age of the tertiary formations, and that of the new red sandstone. - Elie de Beaumont has distinguished four different epochs of disturbance during this period: 1 . that of the Rhenish system affecting the rothetodte and all the substrata; 2 . that of La Vendée and Morvan, to extending the muschelkalk; 3. that of the Erzegebirge, the Côte d'Or and Mount Pilate, including the oolites; and 4. that of the Pyrenees and Appennines, which has also disturbed the cretaceous formations.

Our own island, however, affords us few well marked examples of disturbance during this period, and these scarcely ever afford us sufficient evidence to pronounce on their exact ara; so that we must as yet treat of this part of our subject with a much more vague generality.

In Yorkshire, indeed, in examining the stratification beneath the cretaceous Wolds, we discover that the oolitic series is unconformably arranged, exhibiting a convex curvature and anticlinal line beneath the absolutely horizontal line of junction of the superimposed chalk ; but here the curvature is very gentle, and no signs of violent disturbance are exhibited : this anticlinal line appears to range nearly E. and W. As the chalk and its greensands also at the S.W. extremity in Dorsetshire, werlie the edges of the inferior rocks as far as the red marle, we 
have here again a want of exact conformity; but the difference is scarcely any where sufficient to be sensible to the eye, and can only be recognised by its results on the grand scale: yet these instances are sufficient to show that the elevating forces have acted somewhat differently in the oolitic and cretaceous systems. In Dorsetshire, indeed, the oolites are affected by considerable disturbances in the vicinity of Weymouth, but these appear to have been connected with the convulsions which overthrew the Isle of Wight in the tertiary period. In Yorkshire, we observe on the coast a considerable dislocation of the alum shale near Cloughton: this point is the more worthy of especial notice, because it is situated in the prolongation of the line of the great Cleaveland basaltic dyke, which extends from the central ridge of carboniferous limestone, and ranging nearly in an easterly direction, intersects the coal-measures, new red sandstone, and even the oolites; so that this point indicates a connexion of the disturbances which have here affected the oolitic system with the convulsions and basaltic dykes of the coal-field. The Northumberland coast near the mouth of the 'Tyne presents a still more decided evidence to the same effect (so far at least as the magnesian limestone is concerned); for this latter rock is here thrown down by the great 90-fathom dyke, by far the most important of the faults which affect the Newcastle coal-field, inasmuch as it occasionally deranges the level of the strata on either side of it no less than 140 fathoms. It ranges east and west for about ten miles, when it crosses the Tyne; but in the upper part of the valley of the South Tyne, in the prolongation of this line there is an immense fault, called the Stubbick dyke, operating in the same direction, which may therefore be very probably considered as its continuation, and which occasions a long narrow subsided strip of the upper coal-measures to extend transversely across nearly the whole breadth of the mountain limestone chain; so that we must regard this dislocation as one of the most considerable with which we are acquainted. It affects the magnesian limestone not only at Cullercoats, but seven miles further on its course at Killingworth, and the same distance from any other locality to which the magnesian formation now extends. The depression occasioned by the fault becoming here much more considerable (440 fathoms), a small portion of the lower magnesian sandstone or rothetodte here becomes included, as the upper member of the subsided mass of strata :-the inference is clear, that this sandstone formation must at the period when this subsidence took place have extended continuously to this point; and that therefore its removal over a tract at least six miles 


\section{Rev.W. D. Conybeare on M. de Beaumont's Theory.}

in length, must have subsequently been effected by denuding causes of the most violent agency, excepting where a single fragment of it was sheltered from their action by the depression occasioned by this great fault. On the coast south of Cullercoats this same sandstone is traversed by a basaltic dyke: it is true that our evidence as to the date of the convulsions extends only in Northumberland to the magnesian lime, and in Yorkshire to the alum shale; yet the general analogy of the two cases may incline us to consider them as contemporaneous : but the question will still remain, how much younger they may be than the age of the most recent of those rocks which is associated with the inferior oolite. Their direction is nearly, but not exactly parallel, both ranging nearly $\mathbf{E}$. and W.; but the eastern extremity of the main Newcastle dyke inclines a little to the north, and that of the Cleaveland dyke to the south. The general direction of the faults affecting the intermediate (Durham) coal-field is nearly similar ; and the circumstances I have mentioned render it very desirable to trace the prolongation of their lines towards the overlying range of magnesian limestone, and to examine how far this rock appears affected by them. In the paper on the magnesian limestone, in the Geol. Trans. 2nd series, vol. iii. some trifling faults affecting this rock in Yorkshire are noticed; but their general direction seems to be at right angles to those now noticed, and parallel to the general elevation of the strata.

The traces of the oolitic formations in Scotland have been much disturbed: those in the islands of Mull and Skye by the eruption of the trap rocks, (as we have already noticed, p. 123,) most probably during the tertiary period. The lines of direction are here very variable: along the coast of Sutherland, near the Brora coal-field (which, as in the eastern Moorlands of York, is associated with the inferior oolite), the lias and oolites come in contact with the granitic mountains, and are much disturbed, the lines of direction being variable, but generally inclining to parallelism with the primitive chains which range N.E. and S.W. Although these disturbances are in juxtaposition to the elevated primitive chains, it would be too hasty an inference to refer them to the protrusion of the granite; the granite may already have assumed its actual position relative to these superstrata, and both the primitive and secondary formations may have appeared together at some later epoch. As we have here no younger formations than the oolites to afford us the means of comparison, we must be unable to pronounce definitively how recently these convulsions may have taken place.

[To be continued.] 